Dorset, Gloucestershire, Monmouthshire, Somerset and Wiltshire. This committee was duly elected and requested to report back as soon as possible.

\section{Annual Relief Voyage of R.R.S. John Biscoe}

The R.R.S. John Biscoe left Southampton on October 21 on her annual relief voyage to the Antaretic with staff and supplies for the Falkland Islands Dependencies Survey. The Survey maintains eleven permanent bases along the coast of Graham Land and on islands off the coast. Eighty or so seientists and technicians spend periods ranging from a year to two years at the bases, carrying out surveys, scientific research and meteorological work. Each Antarctic summer, between November and March, the ice of the Antaretic clears sufficiently for specially strengthened ships to make the voyage to the bases with relief staff, supplies and equipment. The present R.R.S. John Biscoe was built for this work. On her way to Port Stanley, she will call at St. Helena and Tristan da Cunha.

\section{Bibliography on Atomic Energy}

A Most useful bibliography of sources of informa. tion on atomic energy taken from a paper $(A . E . R . E$. $\mathrm{Lib} / \mathrm{Ll}$ ) is given in Atom (No. 7, 23 ; May 1957), the monthly information bulletin of the U.K. Atomic Energy Authority. The bibliography covers publications on the work of the Authority ; lists issued by the Authority; general bibliographies; four abstruct journals; fourteen British and Commonwealth, nine American, and eight European periodicals and translated versions of Russian periodicals. A more limited bibliography (A.E.R.E. Inf/Bib 100. Harwell : Information Office, A.E.R.E., Harwell), which has recently been reprinted with additions, lists books published in Great Britain on nuclear energy, nuclear and atomic physies, the measurement of radioactivity, isotopes, and some related topics. It includes both popular expositions and advanced texts written for the specialist, in addition to periodicals in the field of nuclear energy.

\section{Research in Central Africa}

THE seventh annual report of the Institute for Scientific Research in Central Africa (pp. 268. Bruxelles: Institut pour la Recherche Scientifique en Afrique Centrale, 1956) covers the year 1954 and, besides the Director's report and accounts showing expenditure of some 77 million francs, of which 50 million were spent on research at the various research stations, it includes a review by I. H. Vincke of the anti-paludism campaign in Africa south of the Sahara and summaries of papers published during the year by the staff or research workers associated with the Institute. The report records a major study of certain depopulated districts undertaken at the request of the Government of Ruanda. Urundi to determine the facts for a campaign against Glossina responsible for the trypanosomiasis causing the depopulation. Collection of anastomopathological material for neuropathological studies with reference to virus diseases continued at Lwiro, where work on nutrition expanded considerably, particularly biochemical studies on proteins and amino-acids in relation to the nutrition of native children. Observations on birds in the neighbourhood of Tshibati and Lwiro continued, and at Uvira on Lake Tanganyika extensive studies were made of ndekala, a pelagic fish intensively fished in Tanganyika. Besides numerous hydrological observations on the temperature and composition of the water of the lake at various depths, many purely geographical observations were made relatively to its depth in the region of affluents, seasonal variations in temperature, lacustra, etc. Solar observations also continued at Lwiro as well as ionosphere observations and measurements of solar radiation.

\section{The Rings and Satellites of Saturn}

IN a recent paper" entitled "The Effect of the Saturnian Ring upon the Motion of the Satellites" (Publ. Astro. Soc. Japan, 8, No. 1; 1957), Yoshihide Kozai starts with the assumption that the ringsystem of Saturn, composed of a number of small solid particles, consists of two concentric rings with uniform thickness and density, and then proceeds to determine the quantitative effect of the ring on the motion of the satellites. The $A$-ring is supposed to be limited by the radii of $20 \cdot 02^{\prime \prime}$ and $17 \cdot 49^{\prime \prime}$, seen at the mean least distance, and the limits of the $B$ - and $C$-rings are placed at the distances $16 \cdot 90^{\prime \prime}$ and $10 \cdot 49^{\prime \prime}$. Observational data are presented for comparison with the theory, and the values of the mean motions are computed on the assumption that $k / a^{2}=0.024305$, $1 / a^{4}=0$ for the six inner satellites of Saturn. From the solution of the normal equations it seems probable that the mass of the ring is of the order $10^{-4}$ that of Saturn. The precessional motion of the axis of rotation of Saturn is too slow to be detected, even from observations over about a century.

\section{National Science Foundation Fellowships}

THE U.S. National Science Foundation is offering four types of fellowship awards for advanced study and research in the natural sciences during the academic year 1958-59: predoctoral fellowships for college seniors and graduates $(1,600-2,000$ dollars a year); postdoctoral fellowships (3,800 dollars); senior postdoctoral fellowships for candidates who have held a science doctorate for a minimum of five years (up to 10,000 dollars); and seience faculty fellowships for college teachers of science who wish to improve their competence as teachers (up to 10,000 dollars). The awards are open to American eitizens and are tenable at any non-profit-making institution of higher education in the United States or abroad. Fellowships will be awarded in the mathematical, physical, medical, biological, engineering and other sciences, including anthropology, psychology (other than clinical), geography, certain interdisciplinary fields, and areas of convergence between the natural and social sciences. About a thousand awards will be made, to be announced next March. Fellows will be selected on the basis of ability assessed from letters of recommendation, academic records and other evidence of attainment. Applicants for the predoctoral fellowships are required to take the Graduate Record Examination. Forms of application for predoctoral fellowships, which must be completed by January 3, 1958, and for postdoctoral fellowships, which must be completed by December 23, 1957, may be obtained from the Fellowship Office, National Academy of Sciences-National Research Council, 2101 Constitution Avenue, N.W., Washington 25, D.C. Forms of application for senior postdoctoral and science faculty fellowships, which must be completed by January 13, 1958, may be obtained from the Division of Scientific Personnel and Education, National Science Foundation, Washington 25, D.C. 